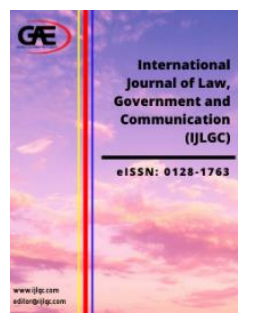

\author{
International Journal of Law, Government and \\ Communication (IJLGC) \\ Journal Website: http://ijlgc.com/ \\ eISSN: 0128-1763
}

\title{
TOWARDS EFFECTIVE COURT- ANNEXED MEDIATION ON COMMERCIAL DISPUTES IN ZANZIBAR
}

\author{
Mzee, Mzee Mustafa ${ }^{1 *}$, Ahmad Azam Othman ${ }^{2}$ \\ 1 PhD Candidate, Ahmad Ibrahim Kulliyyah of Laws, International Islamic University Malaysia, Malaysia \\ Email: mzee.mzee@live.iium.edu.my \\ 2 Ahmad Ibrahim Kulliyyah of Laws, International Islamic University Malaysia, Malaysia \\ Email: aazam@iium.edu.my \\ * Corresponding Author
}

\section{Article Info:}

\section{Article history:}

Received date: 19.02 .2020

Revised date: 10.03 .2020

Accepted date: 14.03.2020

Published date: 15.03.2020

\section{To cite this document:}

Mustafa, M. M., \& Othman, A. A. (2020). Towards Effective CourtAnnexed Mediation on Commercial Disputes in Zanzibar. International Journal of Law, Government and Communication, 5 (18),82-88.

DOI: $10.35631 /$ IJLGC.432008.

\begin{abstract}
:
Commercial activities in Zanzibar are developing every day. This development, however, contributes to the rise of disputes among its key players such as sellers, buyers, suppliers and consumers of goods or services. To ensure the commercial disputes are resolved effectively and speedily the government of Zanzibar has established a commercial court division at the High Court level to settle commercial disputes. One of the procedures of handling commercial disputes in commercial court is through court-annexed mediation. Thus, this paper examines the existing law governing the courtannexed mediation in Zanzibar as a way to find how far it can help to solve commercial disputes effectively without engaging in litigation. The methodology adopted in this paper based on the content analysis of legislations, decided cases, leading textbooks and journal articles. The study also uses a comparative method where necessary to address the study in question. The paper proposes some measures for improving existing courtannexed mediation in Zanzibar such as; amendment of Civil Procedure Decree, making court-annexed mediation compulsory, mediation at subordinate courts and public awareness on the court-annexed mediation.
\end{abstract}

Keywords:

Zanzibar, Court Annexed Mediation, Mediator, Commercial Disputes

\section{Introduction}

Zanzibar is a semi-autonomous country. It is part of the United Republic of Tanzania, which formed after the merger of the then Tanganyika and Zanzibar on $26^{\text {th }}$ April 1964 (Mohammed, 2019). The Constitution of the United Republic of Tanzania gives Zanzibar autonomy to do its internal affairs such as law-making for non- union matters through the 
Zanzibar House of Representatives and its judiciary up to the level of High Court (Article 114 of the Constitution of the United Republic of Tanzania of 1977). Historically Zanzibar was known as a centre for commercial activities for many centuries. This encouraged people from different nations such as Arabs of Oman, British, Indians, Persian and Portuguese to have interest in Zanzibar. Their commercial interest also developed into political interest. This made Zanzibar becomes under the two colonies for the same time the Omanis and the British during the $18^{\text {th }}$ Century (Greenwood, 2016). Like other residents of East Africa, the people of Zanzibar lived in a communal society with traditional dispute settlement based on reconciliation under the council of elder (Stockreiter, 2010). However, after the British occupation, the British established dispute settlement through the court process and extended many laws, which were applicable in India to be applicable in Zanzibar through the successive Orders in Council made under the Foreign Jurisdiction Act (Feingold, 2018), For instance, the Civil Procedure Code of India of 1882 was extended to Zanzibar in 1884 through the Order in Council as the Civil Procedure Decree (Allen \& et al, 2013). This law remains an important law in the administration of civil proceedings in Zanzibar. However, the law has not contained much about alternative dispute resolution, which has been promoted and advocated in the current time. On the other hand, Arbitration Decree, Arbitration Clauses (Protocols) Decree and Arbitration (Foreign Awards) Decree allows the application of the arbitration process in dispute settlement. However, the experience shows that most people are not referring their commercial disputes to arbitration though most of the agreements contain a provision that requires reference to arbitration. This situation has made commercial dispute depends mainly on the litigation process. Therefore, to ensure a quick settlement of the commercial dispute, the government of Zanzibar in 2013 established a High Court Commercial Division to adjudicate commercial disputes through Zanzibar Commercial Court (High Court Division Act) No. 9, 2013. Section 3 of the Zanzibar Commercial Court (High Court Division Act) No. 9, 2013 defines commercial disputes as every kind of dispute arises from the commercial transaction that involves two or more persons. These include but not limited to any dispute concerning the governance of the commercial organization, contractual relationship, the liability of commercial organization, payments of commercial debts, arbitration award, intellectual property and mortgage transactions. Furthermore, the Act allows the settlement of the commercial dispute through court-annexed mediation before trial as a means to settle the dispute amicably. This is a new development in commercial dispute settlement in Zanzibar. Thus, this study analyses the legal provisions and practice which govern the court-annexed mediation in commercial disputes to understand the situation and come up with some recommendations for improvement.

\section{Court-Annexed Mediation and Its Objectives}

Court-annexed mediation is a mediation process conducted by the court after parties filed a case. It is a conflict resolution process in which a court-appointed mediator assists the disputed parties to negotiate through informal settlement. This mediation is also known as compulsory mediation because the law requires the existence of mediation before litigation (Syukur \& Bagshaw, 2013). A judge, court's registrar or private person who has been appointed by the court can conduct the court-annexed mediation (Ervasti, 2018). Thus, courtannexed mediation is amicable dispute settlement under the supervision of the court. The main objective of court-annexed mediation is to improve the civil justice system through a simple and speedier process of resolving the disputes among the disputant parties (Petra, 2018). The Court-annexed mediation has proven to be advantageous for dispute settlement as it helps to minimize the problem of backlog of cases in courts (Choy \& et al, 2016). In addition to that, it fulfils the parties' substantive, procedural and emotional interests and wishes since they play a big role during the mediation process. Based on that, different states 
include United State of America, United Kingdom, Australia, Singapore, and Malaysia have established it as a mandatory process for disputant parties to follow when fail to resolve their dispute in a pre-trial conference (Alexander \& Steffek, 2016). However, this process has been subject to criticisms as it threatening the role of courts in protecting law and justice as required under the rule of law, which in due course weakens the confidence of legal norms. Also, it has argued that the court should limit its function on adjudication only because the involvement of the court in mediation might prejudice the fairness, impartiality and independence of the judiciary that is the fundamental principle of the judiciary ( $\mathrm{Li}, 2016$ ). Hence, most of the people proposed mediation to be conducted outside the court without its involvement. Despite these arguments, court-annexed mediation remains as an important procedure for dispute settlement. The involvement of the court in this process does not eradicate the core principles of the court to do justice without fear and favour since judges are remaining to do justice accordingly without being prejudiced. Moreover, the process does not always involve judges. Sometimes the mediation process conducted by a third party or institution and the court only passes a judgement based on the agreement of the parties during mediation. On the contrary, the involvement of the court in mediation guarantees the enforcement of the agreement of disputant parties during mediation. Since, without a court, disputant parties may dishonour their agreement.

\section{Law and Practice of Court-Annexed Mediation on Commercial Disputes in Zanzibar}

The law that establishes the High Court Commercial Division in Zanzibar has some provisions relating to the court-annexed mediation. Section of 18 of Zanzibar Commercial Court (High Court Division Act) (Act No. 9, 2013) provides that when the disputant parties fail to settle their case during the pre-trial conference, the law requires the court to inform parties to refer their case to mediation and appoint a mediator for them. A person to be qualified as a mediator must hold university degree, knowledge or experience of the law governing the disputed matter, mediation skills and should not be a leader of any business or consumer association (Regulation 4 of the Mediators Qualifications and Remuneration Rules of 2018, L.N 95 of 2018). The mediator is required to finalize the whole mediation process within fourteen days though subject to extension for seven days. However, parties are free to reject their dispute to be referred to the mediation if jointly decide so. This shows that a court-annexed mediation in Zanzibar is not a compulsory process rather an option. This situation does not comply with the current world practice to settle the commercial dispute out of the litigation process. The law should impose a condition to refer the dispute to the mediation as a way to resolve the dispute out of litigation. However, if parties agree to go for mediation the attendance of such mediation must also include a third party who requires indemnifying a party to the mediation or his advocate. The idea is to make him aware of the process and if he argues, he can raise before the court issue a decision. A party who attends mediation must have authority to settle the matter or must have access to obtain approval before agreeing. These conditions are set to ensure mediation agreements are enforceable since it is possible for an agent who represents his principal to agree on something contrarily to the opinion of his principal. Hence, the execution of the agreement will become difficult. Parties are required to attend mediation sessions without missing it, unless if there is a good cause that makes them not to attend. Thus, if the plaintiff fails to appear without a good cause the mediation process will be dismissed and in case of the defendant, his defence will be struck out. In addition to that, a defaulting party is required to pay the cost or the mediator can make any other order that deems fit. However, if the mediator was the reason for such abundance because of the failure to observe the principles of natural justices or honour the wishes of the parties during the process the above remedies will not be applicable. Further, the law requires mediation process to remain confidential during the whole process and any 
statement that is made during the mediation process cannot be accepted in court as evidence. This is to ensure disputant parties are free to express their views during the mediation process without fear that, their statement might be used against them during the litigation. However, the law should not forbid disclosure of mediation communication in court, since in some circumstances disputant parties may agree on disclosure of communication in court for the interest of justice (Dorcas, 2016). Furthermore, the law provides various circumstances that end the mediation process. These include; the impossibility of mediation, settlement agreement and expiring of fourteen required days. Thus, if mediation ends without having a settlement agreement the law requires the dispute to revert to the trial judge who can proceed with the suit from when the suit goes for mediation. On the other hand, the court has the power to remove a mediator due to incapability of performing his function, conducting serious misconduct relating to his function and if either party requested so.

It is clear from the above discussion that, the court-annexed mediation in Zanzibar has some shortcomings. These include; mediation is conducting after the preliminary application, a reference to mediation is not a compulsory and lack of regulations or guideline to regulate the court-annexed mediation. These shortcomings may lead to the perception that court-annexed mediation is not an appropriate method for dispute resolution and opting for litigation. Thus there is a need for effective measures to be taken to rescue the situation.

\section{Measures towards Effective Court-Annexed Mediation in Zanzibar}

Effective court-annexed mediation in Zanzibar is the only way of making commercial disputes to be resolved immediately and efficiently. There are various measures to be carried out to ensure the objectives of having court-annexed mediation are observed. These measures include; law and regulations, compulsory court-annexed mediation, court-annexed mediation at subordinate's courts and awareness of court-annexed mediation.

\section{Law and Regulations}

Currently, the Zanzibar Commercial Court Act is the only law that governs a court-annexed mediation in Zanzibar for commercial dispute. However, it is pertinent to notice that the Commercial Division is not the only court that has jurisdiction over commercial disputes since the ordinary court has also jurisdiction over them. The current situation makes courtannexed mediation exclusively conducted at the Commercial Division. This situation denies an opportunity for disputant parties who filed their cases in ordinary High Court a chance to resolve their dispute through court-annexed mediation. There is a need for court-annexed mediation to form part of the civil procedure system in Zanzibar. Thus, to make courtannexed mediation to become part of the civil system, there is a need of amending the Civil Procedure Decree, Cap 8 by including provisions that allow a court to order a stay of proceedings pending the completion of the mediation. The law should also exclude a judge or magistrate who conducted mediation to preside the same case when mediation becomes unsuccessful to avoid being prejudice with information obtained during mediation sessions. In addition to that, there must be a regulation or guideline, which regulates the entire process of court-annexed mediation. This is to have a uniform in conducting mediation. The lack of guideline allows each mediator to conduct mediation as per his wishes and not for the interest of the justices. In addition to that, there is a need to include a provision of a good character as one among the qualifications for a person to be appointed as mediator. This qualification will help to have a competent mediator who may not be bias or corrupt (Giovanni, 2018). 


\section{Compulsory Court-Annexed Mediation}

Currently, court-annexed mediation is not a mandatory process in Zanzibar. The disputant parties have the option either to refer their dispute to mediation or not. This situation does not guarantee a quick settlement of a dispute. Hence, there is a need for court-annexed mediation to be a compulsory process to reduce the backlog of cases (Kin, 2018). In addition to that, because mediation is in its infancy stage, the judges should remain as a mediator for commercial cases to encourage people to attend the mediation session. Thus, a thorough selection of judges is required to ensure mediation conducted appropriately. However, the court may use retired judges or highly experience advocates to facilitate mediation. Apart from the law, parties should be encouraged to make a binding provision in their contract that shows reference to court-annexed mediation as compulsory before litigation.

\section{Mediation at Subordinate's Courts}

Zanzibar has three levels of subordinate court namely Regional Court, District Court and Primary Court. These courts have also jurisdiction to entertain commercial dispute depends on their pecuniary jurisdiction. For instances, the Regional Court has jurisdiction to hear and determine civil cases which involve commercial cases if the value of the subject matter does not exceed TZS 50,000,000 (USD 21,734.708) for immovable properties and TZS 30,000,000 (USD 13,039.850)for movable property. A District Court has jurisdiction to hear and determine a civil case that involves commercial cases if the value of the subject matter does not exceed TZS 10,000,000 (USD 4,346.6167) for immovable properties and TZS $5,000,000$ (USD 2,173.475) for movable properties. Considering the pecuniary jurisdictions of these courts, some of the commercial disputes will be tried before these courts. However, the law is silent on the application of the court-annexed mediation at these courts. Hence, there is a need to have a court-annexed mediation process at the subordinate courts to reduce the backlog of cases. In addition to that, many cases will end at this level without giving a burden to the High Court to hear appeals from the subordinate courts. Zanzibar should take the example of Tanzania Mainland and Singapore where subordinate courts have jurisdiction to conduct court-annexed mediation.

\section{Awareness of Court-Annexed Mediation}

Court-annexed mediation is a new phenomenon for many people in Zanzibar. Therefore, there is a need for people to be educated on the advantages of using it as opposed to litigation. Since litigation has become very expensive in Zanzibar that most of the people could not afford to pay for the litigation process (Uki, 2019). The government through the ministry responsible for legal affairs must set a special budget to finance awareness activities on court-annexed mediation. Lawyers must act professionally by encouraging their clients to refer their dispute for court-annexed mediation instead of engaging at litigation which costly and time-consuming. Universities should also teach mediation as subject to its law students to prepare them for mediation instead of litigation. The current practice shows that most universities taught mediation as part of alternative dispute resolution. This does not make a student skilled in mediation rather having theory only. In addition to that, while the majority of people in Zanzibar are Muslims (Malengo \& Hamad, 2017), the religious leaders should also encourage people to use it since the concept of mediation (sulh) is emphasised in Islam in different places (Dahlan, 2018). For instance, Allah says “... If a wife fears cruelty or desertion on her husband's part, there is no blame on them if they arrange an amicable settlement between themselves; and such settlement is best."(An-Nisa: 128). Again, it has been reported that the Prophet (PBUH) has said 'sulh among the Muslim parties is encouraged save and except that forbidding a permitted thing or permitting a forbidden thing' 
(Tirmidh). Therefore, all these authorities show that Muslims are encouraged to use mediation as a means of dispute resolution.

\section{Conclusion}

Zanzibar introduced the court-annexed mediation at High Court Commercial division as an option for the disputant parties to refer their dispute. However, the ordinary High Court and the subordinate courts have no mandate to conduct court-annexed mediation. This is associated with a lack of special law that gives a mandate for other courts to use courtannexed mediation. Because of that, the country has also no guideline that guides the process of court-annexed mediation. To ensure effective court-annexed mediation, it was recommended for special law and regulation that give jurisdiction to other courts to conduct court-annexed mediation for commercial dispute. Moreover, court-annexed mediation should be a mandatory process for commercial dispute. To make it court-annexed and known to the public the government and religious leaders must create awareness to the people on advantages of mediation.

\section{References}

Alexander, N. \& Steffek, F. (2016) "Making Mediation Law". Available at http://ink.library.smu.edu.sg/sol_research/2232 accessed on $10^{\text {th }}$ February 2019.

Allen, R.J., Timothy, Fry., Notebaert, Jessica., \& VanDam, J. (2013), "Reforming the Law of Evidence of Tanzania (Part One): The Social and Legal Challenges", Boston University International Law Journal, Vol. 31, pp. 217-266.

Choy, C.Y, Tie, F. H. \& Siang, C.O (2016) "Court-Annexed Mediation Practice in Malaysia: What the Future Holds" University of Bologna Law Review, Vol. 1, pp. 271-308.

Ervasti, K. (2018), Past, Present and Future of Mediation in Nordic Countries, Cham: Springer.

Feingold, E. R. (2018), Colonial Justice and Decolonization in the High Court of Tanzania, 1920-1971, Switzerland: Springer International Publishing.

Giovanni, M. (2018), International Commercial Mediation, an Opportunity for the OBOR, In Chaisse, J \& Górski, J (eds), the Belt and Road Initiative: Law, Economics and Politics, Leiden: Koninklijke, Brill NV.

Greenwood, A (2016), the Colonial Medical Service and the Struggle for Control of the Zanzibar Maternity Association, 1918-47, In Greenwood, A Colonialism; Medicine; Colonial Service; Empire; Missionaries; Government, Manchester: Manchester University Press.

Kin, L. S. (2018), "What is the Solution behind the Problem?" Available at http://www.mediation.com.sg/assets/Speeches/Unfolding-Conversations-2018Speech.pdf accessed on 25th November, 2019.

Li, Y. (2016) "From "Access to Justice" to "Barrier to Justice"? An Empirical Examination of Chinese Court-Annexed Mediation”, Asian Journal of Law and Society, Vol. 3, pp. 377-397.

Mohammed, M. S. (2019), "Prospect of Secularism and the Muslim Society of Zanzibar", International Journal of Research and Innovation in Social Science, Vol. 3, No. 5, pp. 307-313.

Petra, H. (2018), "Mediation and the Legal System Extracting the Legal Principles of Civil and Commercial Mediation", PhD thesis: University of Helsinki.

Quek Anderson, Dorcas, Q.A. (2017), “A Coming of Age for Mediation in Singapore? Mediation Act 2016", Singapore Academy of Law Journal, Vol. 29, pp. 275- 293. 
Stockreiter, E.E. (2010), "British Kadhis" and "Muslim judges": Modernization, Inconsistencies and Accommodation in Zanzibar's Colonial Judiciary," Journal of Eastern African Studies, Vol. 4, No. 3, pp. 560-576.

Syukur, F. A \& Bagshaw, D. M. (2013), "Court-Annexed Mediation in Indonesia: Does Culture Matter?" Conflict Resolution Quarterly, Vol. 30, pp. 369-390.

Uki, A. A. (2019), Access to Justice to All and the Constitution of Zanzibar 1984: A Social Legal Analysis, Zanzibar: ABG Printing Press. 